\title{
FAKTOR-FAKTOR YANG MEMPENGARUHI KEPUTUSAN WISATAWAN NUSANTARA BERWISATA BELANJA DI RAMA KRISNA OLEH-OLEH KHAS BALI
}

\author{
I Kadek Adi Sumara Putra \\ I Ketut Suwena \\ I Made Kusuma Negara \\ Email : adisumaraputra@ymail.com \\ PS. S1 Industri Perjalanan Wisata \\ Fakultas Pariwisata UNUD
}

\begin{abstract}
The activities of shopping trips into one of the attractions which is most favorite by domestic tourists. It can be seen from the percentage of domestic tourists who's doing activity for shopping tour that is equal to 35 percent. The tourism shopping center that are currently being developed and are Frequently visited by domestic tourists is Rama Krishna Oleh-Oleh Khas Bali as a tourism shopping center of handicrafts from Bali with modern nuances. The purpose of this study was to determine the factors influencing the domestic tourists decision who's doing activities for shopping trips and also determine the dominant factors that influence the domestic tourists decision for shopping trips in Rama Krishna Oleh-Oleh Khas Bali. This research using purposive sampling with distributing questionnaires to 374 respondents who traveled shopping at Rama Krishna Oleh-Oleh Khas Bali. The data were collection by observation, questionnaire interview, and library research. This research is being tested first for its validity and reliability before being by factor analysis. The results of this research showed that 18 variables were identified, 15 variables were selected into the three factors that influence the domestic tourists decision for shopping trips. Those factors consist of psychological factors with eigenvalue of 5.587, situational factors with eigenvalue of 1.594, and external factors with eigenvalue of 1.117. From the result of analysis factors well known that the most dominant factor were influencing domestic tourists decision for shopping trips in Rama Krishna Oleh-Oleh Khas Bali is a psychological factor because it has the highest eigenvalue of all factors that have been formed. The variables included in the psychological factors are: motivation, personality, learning, attitudes, and perceptions.
\end{abstract}

Keywords: Buying Decision, Shopping Tourism, Factor Analysis.

\section{PENDAHULUAN}

Dewasa ini jenis kegiatan wisata yang diminati oleh wisatawan sangat beragam. Seiring dengan perkembangan zaman yang semakin modern, pelaku wisata dituntut untuk menciptakan kreasi dan inovasi dalam mengembangkan kepariwisataan di setiap daerahnya masing-masing. Hal ini dilakukan agar wisatawan yang kembali datang berkunjung tidak jenuh atau merasa bosan dengan jenis kegiatan wisata yang ditawarkan. Setiap wisatawan memiliki motif yang berbeda-beda ketika memutuskan untuk melakukan perjalanan wisata. Bali pada umumnya dikenal sebagai daerah tujuan wisata yang memiliki keindahan alam dan keanekaragaman budaya yang mana mampu untuk menarik minat dari wisatawan, baik itu mancanegara maupun nusantara untuk datang berkunjung. Selain dari 2 faktor tersebut, industri pariwisata yang ada di Bali terus berkembang dan menjadi sarana pendukung bagi sektor pariwisata yang ada di Bali. Adapun salah satu industri pariwisata yang menjadi perhatian khusus saat ini adalah pasar oleh-oleh modern sebagai pusat wisata belanja yang saat ini diminati oleh para wisatawan domestik pada umumnya. Hal ini dapat dilihat 
dari persentase wisatawan nusantara yang mengunjungi Bali berdasarkan jenis-jenis kegiatan/atraksi wisata yang dilakukan pada Tabel 1.

Tabel 1. Persentase Wisnus yang Berkunjung ke Bali Berdasarkan Jenis Kegiatan.

\begin{tabular}{llr}
\hline No. & Jenis Kegiatan Wisata & \multicolumn{2}{c}{$\begin{array}{l}\text { Presentase } \\
(\%)\end{array}$} \\
\hline 1 & Sight Seeing (melihat- & 46,4 \\
& lihat) & \\
2 & Adventure (trekking, & 3,0 \\
& rafting, surfing, dsb. ) & 35,0 \\
3 & Shopping (berbelanja) & 2,6 \\
4 & Religius/Spiritual & 0,5 \\
5 & Wellness (kesehatan) & 1,5 \\
6 & Night Life (hiburan & 11,0 \\
\multirow{2}{*}{7} & malam) & 100,0 \\
\hline & Lainnya & Jumlah
\end{tabular}

Sumber: Dinas Pariwisata Provinsi Bali, 2016.

Berdasarkan Tabel 1, maka dapat dilihat bahwa wisatawan nusantara yang berkunjung ke Bali memiliki tujuan berwisata yang berbeda-beda. Salah satu yang menjadi perhatian yaitu tingginya jenis kegiatan berwisata belanja (shopping tourism) dengan persentase sebesar $35,0 \%$. Hal ini menunjukan bahwa ketertarikan wisatawan domestik untuk berwisata belanja oleh-oleh sangat besar. Wisata belanja dapat disimpulkan sebagai kegiatan perjalanan yang dilakukan oleh seseorang atau kelompok dengan mengunjungi tempat tertentu untuk membeli barang maupun jasa yang ada di lokasi tersebut (Sulung,2009: 3).

Adapun tempat wisata belanja yang saat ini sedang berkembang salah satunya adalah Rama Krisna Oleh-oleh khas Bali sebagai pusat wisata belanja oleh-oleh khas dari Bali yang bernuansa modern. Berkembangnya Krisna Oleh-oleh khas Bali tidak lepas dari banyaknya jumlah kunjungan wisatawan yang memutuskan untuk datang dan melakukan kegiatan wisata belanja ke Bali. Adapun wisatawan yang dominan sering datang ke pusat perbelanjaan khas Bali tersebut adalah wisatawan nusantara, baik secara perorangan, keluarga, maupun jumlah besar.

Keputusan pembelian oleh wisatawan nusantara yang saat ini lebih banyak memilih untuk berwisata belanja di pasar oleh-oleh modern daripada pasar oleh-oleh tradisional menjadi suatu fenomena yang harus dianalisa. Selain itu juga berdasarkan wawancara tidak disengaja yang dilakukan menyatakan bahwa wisatawan lebih memilih untuk berwisata belanja di Rama Krisna Oleh-oleh khas Bali karena faktor lokasi yang strategis dan harga.

Mengarah pada keputusan wisatawan dalam menentukan tempat untuk berwisata belanja, maka dapat dijelaskan tujuan dari penelitian ini yaitu untuk mengetahui faktorfaktor yang mempengaruhi keputusan wisatawan nusantara untuk melakukan kegiatan berwisata belanja dan juga mengetahui faktor dominan yang mempengaruhi keputusan wisatawan nusantara berwisata belanja di Rama Krisna Oleh-oleh khas Bali.

\section{METODE}

Adapun data diambil pada Rama Krisna Oleh-oleh khas Bali yang berlokasi di Jl.Raya Tuban No.2x. Variabel data yang digunakan terdiri dari 4 variabel dan 18 indikator. Variabel pertama yaitu psikologis, terdiri dari indikator persepsi, motivasi, pembelajaran, sikap, dan kepribadian. Variabel ke dua yaitu situasional, terdiri dari indikator sarana dan prasarana, waktu belanja, penggunaan produk, dan kondisi pembelian. Variabel ketiga yaitu sosial yang terdiri dari peraturan/undangundang, keluarga, referensi, kelas sosial, dan prestise. Variabel yang keempat yaitu bauran pemasaran $(4 \mathrm{p})$, terdiri dari product, price, place, dan promotion.

Teknik observasi, wawancara, penyebaran kuisioner, dan sudi kepustakaan dipergunakan untuk pengumpulan data. Purposive sampling digunakan untuk menentukan sampel. Besarnya jumlah sampel yang dipergunakan sebanyak 374 responden, mengacu pada metode dari slovin. Teknik analisis data yang dipergunakan adalah kualitatif dan deskriptif kuantitatif dengan menggunakan program SPSS untuk mengolah data kuisioner dengan uji validitas, reliabilitas, dan analisis faktor.

\section{HASIL}

Rama Krisna Oleh-oleh khas Bali merupakan sebuah pusat perbelanjaan oleholeh modern dengan nuansa budaya khas dari Bali. Rama Krisna berdiri secara resmi pada tanggal 1 November 2010 dengan konsep buka 24 jam non stop. Karakteristik wisatawan 
dalam hal ini bertujuan untuk mengetahui identitas responden secara lengkap dan juga dapat mengetahui target pasar dari subjek yang diteliti. Diperoleh 374 responden yang didapat dengan cara teknik penyebaran kuisioner kepada wisatawan nusantara yang berbelanja di Rama Krisna Oleh-oleh khas Bali. Adapun hasil dari karakteristik wisatawan tersebut, yaitu didominasi oleh wisatawan yang berasal dari Surabaya dengan persentase sebesar $47,4 \%$ berdasarkan daerah asal, kemudian untuk jenis kelamin didominasi perempuan sebesar 55,4\%, untuk faktor usia didominasi oleh wisatawan yang berumur antara 15-35 tahun sebesar $52,1 \%$.

Berdasarkan status didominasi oleh wisatawan yang sudah menikah dengan persentase sebesar 58,1\%, berdasarkan pendidikan didominasi oleh wisatawan yang memiliki latar belakang pendidikan S1 sebesar $49,3 \%$, untuk faktor pekerjaan didominasi oleh wisaawan yang berprofesi sebagai wiraswasta sebesar 36,2\%. Berdasarkan lamanya kunjungan belanja lebih dominan terhadap wisatawan yang menghabiskan waktu belanja 1 jam dengan persentase sebesar 57,5\%, kemudian untuk mode transportasi yang digunakan menuju Rama Krisna Oleh-Oleh Khas Bali lebih dominan terhadap wisatawan pengguna transportasi mini bus/Elf sebanyak 157 orang, kemudian untuk sumber informasi yang didapat, didominasi oleh wisatawan yang mengetahui melauli teman/kerabat sebanyak 258 orang, dan untuk biaya belanja yang dikeluarkan, didominasi oleh pengeluaran biaya antara Rp.2.000.000-Rp.5.000.000 oleh wisatawan dengan persentase sebesar $58,5 \%$.

Uji validititas digunakan sebagai alat ukur untuk menguji keabsahan data pada kuisioner. Dalam peneitian ini terdapat 17 indikator yang valid dari ke 18 indikator yang di uji. Adapun satu indikator yang invalid adalah prestise dikarenakan nilai $r_{\text {hitung }}$ kurang dari 0,367 dan tidak bias diproses ke uji berikutnya. Pengujian reliabilitas dilakukan untuk memperoleh hasil yang reliable. Dalam penelitian ini diperoleh hasil angka dari nilai alpha cronbach's sebesar 0,889 yang berarti nilai tersebut telah memenuhi syarat atau reliable $>0,6$.

Proses analisis faktor dalam penelitian ini dipergunakan untuk mengetahui faktorfaktor yang menpengeruhi keputusan wisatawan domestik berwisata belanja di Rama Krisna Oleh-oleh khas Bali. Langkah pertama dari analisis faktor yaitu merumuskan masalah, dimana dapat diidentifikasi dari 17 variabel penentu keputusan pembelian dengan responden sebanyak 374 orang. Kemudian, dilakukan proses uji Bartlett's (Bartlett Test of Sphericity) yang memperoleh nilai sebesar 1818,33 dengan signifikansi 0,000 yang menunjukan peluang untuk terjadinya kesalahan pada variabel yang tidak independen sebesar $0 \%$.

Tahapan berikutnya yaitu dilakukan dengan proses uji Kaiser-Meyer-Olkin (KMO), dimana nilai dari uji ini menunjukan syarat kecukupan yang sudah melebihi 0,5 yaitu 0,898 dan bisa dilanjutkan ke proses berikutnya. Uji Measure of Sampling Adequacy (MSA) dalam penelitian ini bertujuan untuk mengukur derajat korelasi antar variabel yang memiliki nilai MSA $>0,5$, sehingga dapat diketahui dari ke 17 variabel yang ada telah memenuhi syarat dari nilai minimum MSA.

Pada tahap berikutnya dilakukan penentuan jumlah faktor yang mana dalam penelitian ini terbentuk 3 (tiga) faktor dari 17 variabel yang mempengaruhi keputusan wisatawan domestik dalam berwisata belanja. Ketiga faktor tersebut memiliki eigenvalue $\geq$ 1 , yaitu 5,$871 ; 1 ., 594$; dan 1,117 dengan nilai dari Cumulative eigenvalue sebesar 51,163\%. Tahapan berikutnya yaitu proses rotasi faktor, dimana dari ke 17 variabel yang telah dirotasi, terdapat 15 variabel yang memenuhi syarat loading factor $>0,5$ dan 2 variabel yang tidak memenuhi kriteria, yaitu variabel penggunaan produk dan kelas sosial.

Proses berikutnya yaitu dilakukan interpretasi faktor dengan mengelompokan variabel ke dalam 3 faktor yang telah terbentuk. Faktor yang pertama diberi nama faktor psikologis yang memiliki nilai eigenvalue sebesar 5,587 dan terdiri dari variabel motivasi, kepribadian, pembelajaran, sikap, dan persepsi. Faktor yang ke-2 yaitu faktor situasional dengan nilai eigenvalue sebesar 1,594 dan terdiri dari variabel kondisi pembelian, peraturan/ undang-undang, referensi, tempat (place), waktu belanja, serta sarana dan prasarana. Faktor yang ke 3 adalah faktor eksternal yang memiliki nilai eigenvalue sebesar 1,117. Adapun faktor eksternal terdiri dari variabel produk (product), harga (price), promosi (promotion), dan keluarga. 


\section{PEMBAHASAN}

Karakteristik wisatawan dalam penelitian ini bertujuan untuk mengetahui identitas responden secara lengkap dan juga dapat mengetahui target pasar dari subjek yang diteliti. Karakteristik wisatawan di identifikasi melalui 10 indikator sebagai berikut : daerah asal, jenis kelamin, usia, status, pendidikan, pekerjaan, lama berbelanja, mode transportasi, sumber informasi, dan biaya berbelanja. Adapun hasil yang didapat, menunjukan 10 karakteristik yang dominan berwisata belanja ke Rama Krisna Oleh-Oleh Khas Bali, antara lain : wisatawan yang berasal dari Surabaya $(47,4 \%)$, wisatawan yang berjenis kelamin perempuan $(55,4 \%)$, wisatawan yang berumur antara $15-35$ tahun $(52,1 \%)$, wisatawan yang sudah menikah $(58,1 \%)$, wisatawan yang memiliki latar belakang pendidikan S1 $(49,3 \%)$, wisaawan yang berprofesi sebagai wiraswasta $(36,2 \%)$, wisatawan yang menghabiskan waktu belanja 1 jam $(57,5 \%)$, wisatawan pengguna transportasi mini bus/Elf ( $42,1 \%$ orang), wisatawan yang mengetahui melauli teman/kerabat $(65,4 \%)$, dan pengeluaran biaya antara Rp.2.000.000Rp.5.000.000 oleh wisatawan $(58,5 \%)$.

Hasil dari analisis data menggunakan program SPSS dengan metode analisis faktor. Adapun hasil yang diperoleh menunjukan bahwa dari ke 4 (empat) faktor awal dengan total 18 variabel diatas, maka faktor-faktor yang mempengaruhi keputusan wisatawan nusantara berwisata belanja di Rama Krisna Oleh-oleh khas Bali menghasilkan 3 faktor terbentuk dengan 13 variabel didalamnya. Hal tersebut dapat diuraikan sebagai berikut : Faktor psikologis dengan variabel sebanyak 5 yaitu motivasi, persepsi, pembelajaran, sikap, dan kepribadian. Faktor situasional dengan variabel kondisi pembelian, peraturan atau undang-undang, referensi, tempat (place), waktu belanja, serta sarana dan prasarana. Faktor eksternal dengan variabel produk (product), harga (price), promosi (promotion), dan keluarga.

Faktor-faktor yang telah diproses menghasilkan nilai eigenvalue yang tertinggi dari keseluruhan faktor yang terbentuk, maka faktor yang paling dominan dalam mempengaruhi keputusan wisatawan untuk melakukan kegiatan berwisata belanja adalah faktor psikologis dengan 5 variabel didalamnya, yaitu: motivasi, kepribadian, pembelajaran, sikap, dan persepsi.
Hasil analisis faktor ini diperkuat dengan hasil observasi dan wawancara. Ini bertujuan untuk mengetahui alasan dari wisatawan secara lisan, selain dari hasil analisis faktor. Adapun hasil yang didapat menunjukan bahwa sebagian besar yang mempengaruhi keputusan wisatawan untuk melakukan kegiatan berwisata belanja adalah faktor psikologis itu sendiri, karena wisatawan memiliki motif dan keinginan yang tinggi untuk berwisata belanja, kemudian juga ada yang berpendapat bahwa kegiatan berwisata belanja menjadi tren atau kebiasaan bagi wisatawan nusantara ketika melakukan perjalanan wisata ke suatu destinasi. Selain itu, faktor kepercayaan terhadap citra merek dan juga pandangan yang positif terhadap perusahaan yang menawarkan berbagai macam oleh-oleh juga menjadi ketertarikan tersendiri bagi wisatawan. Dan terdapat juga alasan bahwa melakukan kegiatan berwisata belanja sudah dilakukan di masa lampau, sehingga sudah menjadi kebiasaan bagi wisatawan nusantara.

Sedangkan sisanya mengatakan bahwa faktor yang mempengaruhi wisatawan untuk berwisata belanja adalah karena faktor situasional yang terdiri dari tempat atau lokasi yang strategis, waktu berbelanja yang tak terbatas, keadaan sarana dan prasarana yang mendukung, kondisi fisik yang baik untuk mendukung aktivitas dalam berwisata belanja, rekomendasi dari keluarga, teman, ataupun kelompok referensi yang pernah berwisata belanja, dan juga produk yang berkualitas karena telah memiliki ijin yang berlaku (legal). Faktor yang terakhir yaitu eksternal terdiri dari pengaruh terhadap produk (product), harga (price), promosi (promotion), dan juga dorongan langsung dari anggota keluarga itu sendiri.

Hasil dari penelitian ini juga diperkuat oleh penelitian sebelumnya yang dilakukan oleh Hasan Hussaen, dkk (2013) yang membahas "faktor-faktor yang mempengaruhi keputusan wisatawan dalam melakukan kunjungan wisata di Kota Tidore Kepulauan". Hasil dari penelitian ini menunjkan bahwa faktor yang paling dominan adalah faktor psikologi.

Mengacu pada hasil penelitian diatas dan juga hasil pendukung dari penelitian sebelumnya, maka dapat disimpulkan bahwa wisatawan yang berwisata belanja di Rama Krisna Oleh-Oleh Khas Bali sebagian besar 
dipengaruhi oleh motivasi, kepribadian, pembelajaran, sikap, dan juga persepsi. Ini merupakan hal penting yang membuat wisatawan memutuskan untuk melakukan kegiatan berwisata belanja.

\section{SIMPULAN \& SARAN \\ Simpulan}

Faktor-faktor yang mempengaruhi keputusan wisatawan nusantara berwisata belanja di Rama Krisna Oleh-oleh khas Bali, yaitu: faktor psikologis yang meliputi variabel motivasi, kepribadian, pembelajaran, sikap, dan persepsi, faktor situasional yang meliputi 5 variabel, yaitu kondisi pembelian, peraturan atau undang-undang, tempat (place), waktu belanja, serta sarana dan prasarana, dan faktor eksternal yang meliputi variabel produk (product), harga (price), referensi, promosi (promotion), dan juga variabel keluarga.

Faktor yang paling dominan atau yang paling tinggi dalam mempengaruhi keputusan wisatawan nusantara untuk berwisata belanja adalah faktor psikologi. Hal ini dapat dilihat dari tingginya motivasi dan keinginan dari wisatawan untuk berwisata belanja, kemudian kegiatan berwisata belanja menjadi tren atau kebiasaan bagi wisatawan nusantara ketika melakukan perjalanan wisata ke suatu destinasi. Selain itu, adanya kepercayaan terhadap citra merek dan juga pandangan yang positif terhadap perusahaan yang menawarkan berbagai macam oleh-oleh menjadi ketertarikan tersendiri bagi wisatawan, dan juga dapat diketahui bahwa adanya pengalaman berwisata belanja sebelumnya oleh wisatawan dimasa lampau.

\section{Saran}

Meningkatkan sistem pemasaran perusahaan, terutama dalam hal promosi yang harus lebih inovatif untuk dapat menarik minat wisatawan, khususnya wisatawan mancanegara yang masih minim untuk berkunjung dan hanya didominasi oleh wisatawan nusantara.

Diharapkan meneliti subjek penelitian yang berbeda, dimana pada penelitian ini hanya menggunakan wisatawan nusantara dan untuk penelitian selanjutnya diharapkan dapat meneliti wisatawan mancanegara sebagai subjek penelitian.

\section{DAFTAR PUSTAKA}

Bagus Rai Utama, I Gst dan Eka Mahadewi, Ni Made. 2012. Metodologi Penelitian Pariwisata Perhotelan. Yogyakarta : Andi Offset.

Disparda Bali, 2016. Analisis Pasar Wisatawan Nusantara 2015. Denpasar: Dinas Pariwisata Provinsi Bali.

Hasan, Husein, dkk. 2013. Faktor-Faktor yang Mempengaruhi Keputusan Wisatawan dalam Melakukan Kunjungan Wisata Di Kota Tidore Kepulauan. Makasar : Universitas Hasanudin. http://pasca.unhas.ac.id

Sangadji, Etta Mamang dan Sopiah. 2013. Perilaku Konsumen Praktis. Yogyakarta: Penerbit Andi.

Sugiono. 2009. Metode Penelitian Bisnis (Pendekatan Kuantitatif, Kualitatif, dan $R \& D)$. ALFABETA : Bandung 2015 Metode Penelitian Kuantitatif, Kualitatif, dan $R \& D$ : Best Seller. Bandung, Penerbit ALFABETA. 